\title{
The Media Construction of Climate Change Quiescence: Veiling the Visi- BILITY OF A SUPER EMITTER
}

\author{
RAYMOND MURPHY
}

\begin{abstract}
Castells hypothesized two possibilities concerning global warming: i) a world awakening to the danger with policies to reverse it, or ii) the defense of productivism at all costs. Canada is presently pursuing economic benefits of a fossil-fuel superexporter, which makes it a superemitter. By focusing on the discursive legitimation of practices that cause anthropogenic climate change, this article shows how communication power in the Canadian mass media veils the adverse consequences of extracting oil from bituminous sand. It demonstrates how concern about emissions is dampened and quiescence socially constructed. The mediation between scientific warnings of danger and polluting social practices by media communication power constitutes an important element explaining why Canada's emissions are increasing. It also explains why science, an institution claimed to be particularly influential in reflexive, cosmopolitan modernization, is having little influence in societies like Canada when it brings troubling news. The article shows how a scientifically documented environmental problem becomes a societal non-problem.
\end{abstract}

Keywords: Climate Change, Media, Communication Power, Oil, Social NonProblem

Résumé. Castells a avancé deux possibilités concernant le changement climatique global : i) un monde éveillant au danger avec des politiques pour le renverser, ou ii) l'insistance sur le productivisme peu importe le coût. Présentement le Canada poursuit les bénéfices économiques d'un puissant exportateur de pétrole, ce qui le rend un fort émetteur de gaz à effet de serre. En examinant la légitimation discursive des pratiques qui causent le changement climatique anthropogénique, cet article démontre comment les médias au Canada jettent un voile sur les conséquences adverses de l'extraction du pétrole des sables bitumineux. L'inquiétude à propos des émissions a été diminuée et un état de quiescence construit. $\mathrm{La}$ médiation par les médias entre les avertissements scientifiques du danger et les pratiques polluantes constitue un élément important de l'explication de la hausse des émissions au Canada. Cette médiation explique également pourquoi la science, supposément une institution ayant beaucoup d'influence dans la moderni- 
sation réflexive et cosmopolite, a peu d'influence dans les sociétés telles que le Canada quand elle apporte des conclusions troublantes. L'article démontre comment un problème environnemental, qui a été bien documenté par la science, devient sans importance dans la société.

Mots clés: Changement Climatique, Médias De Communication, Pétrole, Émissions À Effet De Serre.

\section{INTRODUCTION}

M edia and mediation are crucial concepts, especially for understanding the interaction between social constructions and constructions of the biophysical world. Those concepts are significant in two different but related ways. First, constructions of the biophysical world, namely the atmosphere, water, and land, are media that mediate relationships between human groups. For example, the atmosphere is a medium that carries causal relationships between groups in space and time. Carbon dioxide emissions from affluent societies cause global atmospheric warming that threatens harm for vulnerable, distant societies, such as ocean rise damaging Bangladesh and accelerated desertification affecting Chad. Those emissions, whose molecules remain in the atmosphere for a century, also threaten adverse consequences for the biophysical environment future generations will need. The molecules will subsequently descend into oceans acidifying them and continue affecting future generations. Human activities have impacts on other humans through the medium of the environment. Invisible, odourless greenhouse-gas emissions are particularly insidious because a big emitter will foul not only its own nest but also the nest of everyone else because atmospheric currents circulate around the globe.

The second way that 'media' and 'mediation' are important is sociocultural. Science has become society's primary culture of legitimation (Rayner 2010: 2619), but its conclusions of danger do not straightforwardly prompt action to avoid that danger because of the mediation of market dynamics, political interests, media cultural influences, or all three. This article will examine how scientific warnings are mediated by print and electronic mass media and inflected in ways that influence public interpretations of social practices producing anthropogenic climate change. The mass media, not to be confused with alternative media, independent media, etc., is the focus of this analysis because of its expansive reach and dominance. ${ }^{1}$

1. From here on, the term 'media' refers to the mass media. 
Beck $(1999,2006)$ proposes a theory of reflexive change from organized irresponsibility towards global cosmopolitan responsibility for humanity as a whole, but concerning climate change some prosperous societies are reflexivity leaders whereas others are laggards. The article examines why some wealthy societies that are longstanding emitters are increasing their emissions despite scientific warnings of danger. This has been referred to as "anti-reflexivity" (McCright and Dunlap 2010) because it involves rejection of or apathy toward those warnings, and as "anti-ecological economic modernization" (Murphy 2012). The article studies the role of the media when "'organized irresponsibility' becomes a key feature of the drama" (Lester 2010: 178) of climate change.

Specifically the article investigates the case of a wealthy society that is not only one of the world's highest per capita greenhouse-gas emitters but also one of the fastest growing emitters among wealthy societies since 1990. It studies Canada's actions in pursuit of its aspiration to become an energy superpower, which has made it a super emitter, and particularly Canada's fastest growing source of emissions, the Alberta bituminous sands. The objective of the article is to investigate substantive arguments of fossil-fuel legitimation, namely the rhetorical devices used in the media to dampen concern about climate change (Young and Dugas 2011) and promote increased dependence of the Canadian economy on the export of fossil fuels using high emissions for extraction.

\section{Legitimacy Staged on the Media Platform: Communication Power, Privileged Voices, and Diversion}

Castells (2009: 53) argues that power in contemporary network society consists of communication power embedded in the media. They are the means by which discourses that influence action are constructed and propagated. People make up their minds about issues, including environmental issues, according to how they are framed in the media. One type of framing is done through paid advertisements much like any other consumer product marketing. Castells (2009: 199) distinguishes this from regular news, but it is also important to take into account a third type of framing, namely editorial/commentary framings in the media. This dimension of what Castells calls "spinning the news" (2009: 224) has grown in volume, and tries to shape how the public interprets the news, including scientific news about climate change. It consists of constructing meaning, structuring public values and interests, and setting agendas.

Environmental movements employ the media to influence policy and promote change by using celebrities, scripting catastrophic narratives based on fear, etc. Castells (2009: 337) presumes this has been success- 
ful: "after decades of effort by the environmental movement to alert the public to the dangers of climate change by reprogramming the communication networks to convey its message, the world has finally awakened to the threat of self-inflicted destruction that global warming represents" and is adopting policies to reverse the process. Rather than seeing this as an evolution of "the world", accuracy requires analyzing it as a variable differentiating groups and societies. Castells (2009: 304-5) qualifies his optimism by cautioning that "power relationships embedded in the institutions and culture of our societies were adamant about defending the culture of productivism and consumerism at all costs".

Beck $(1995,2000)$ contends that the media are central not only in circulating knowledge about environmental risk, but also in its interpretation and rejection, which he refers to as veiling hazards. The media are important sites for staging conflicts over the environment, which leads to the formation of different publics with particular views about environmental issues. How do media gatekeepers translate scientific conclusions into public understanding or misunderstanding and how do they set the agenda for debate in the public sphere? Powerful groups and "privileged definers" (Hall et al. 1978: 64-5) stigmatize opposing views as extreme. A typical strategy of these privileged definers is to become "sowers of uncertainty" (Pollack 2005), whether it be about harmful consequences of DDT, cigarettes, acid rain, CFCs, and now fossil fuels. Scientists and environmental activists do find ways to get their message out, but they are vastly outspent by profit-seekers who promote economic growth at any risk (Lester 2010). In a media field of negotiated meanings where some parties have greater access and power than others, rhetoric is more than just language. Rhetoric frames the terms of the debate and thereby frames what is considered legitimate action, and thus plays a powerful role in shaping outcomes. Socially constructing legitimacy is particularly important for actions that cause harm, such as those involved in anthropogenic climate change (Davidson and Gismondi 2011). In a greenhouse-gas emissions increasing country and world, it is crucial to study rhetorical devices used by privileged media definers to legitimate emissions.

Freudenburg (2005: 104) argues that harmful practices are made possible by "diversionary reframing - attempting to divert attention away from an uncomfortable question by trying to reframe the debate as being 'about' something else, preferably about the credibility of their critics". This distraction is often accomplished "through the taken-for-granted but generally erroneous assumption that the environmental harm 'must' be for the [economic] benefit of us all" (Freudenburg 2006: abstract). Communication power is effective "because accounts have been repeat- 
ed so often, with so little challenge, as to become taken for granted or 'embedded' within everyday language itself' (Freudenburg 2005: 105). The diversion of attention results in "a kind of 'disappearing act' for questions" (Freudenburg 2006: 20) that are inconvenient. Whereas constructionist sociologists have examined how some conditions come to be perceived as social problems commanding political attention (Hannigan 1995), Freudenburg (2005: 105) complements this by its less researched obverse, namely investigating "the social construction of quiescence or 'non-problematicity" of issues. He and McCright and Dunlap (2010) document how and why it is that some conditions do not come to be perceived as social problems and do not command political attention even when the preponderance of scientific evidence indicates they are dangerous. Rayner (2012) argues that denial, dismissal, diversion and displacement are four strategies institutions use to exclude uncomfortable knowledge and thereby construct ignorance. Davidson and Gismondi (2011: 9) found that legitimacy of inequities and irrationalities are maintained when contradictions are unacknowledged, either concealed or discounted: "It is not contradictions themselves, but the interpretations of those contradictions, that direct avenues of response. We can learn a great deal about legitimacy, then, by exploring the ongoing discursive practices", particularly in the mass media. Freudenburg concludes that investigating relationships between power over resources and power over discourses yields insights into not only environmental problems but also the nature of power.

These distinguished authors provide the framework for a critical analysis of media discourse that legitimates fossil fuels and fosters quiescence concerning environmental problems like climate change. They go beyond conventional research on how environmental movements use the media to construct a sense of environmental problems to more original research into how communication power of the media is used to transform what science concludes is a problem into a societal nonproblem. The media mediate between scientific conclusions and public understanding, thereby inflecting social practices toward either danger-minimizing or danger-maximizing practices. Privileged media opinion leaders characterize problems either as requiring immediate attention or of lesser priority, thereby making problems either top of mind to solve them, or pushing them to the back of the mind by overriding them with economic goals. 


\section{Methodology}

This article will first document that it is dealing with a serious environmental problem by briefly outlining scientific conclusions concerning climate change and Canada's and Alberta's performance. It will then examine mass media commentary that mediates between scientific conclusions and social practices. To investigate how a scientifically determined problem becomes a societal non-problem, the article will purposefully select and assess the main arguments in commentary legitimating Canada's fossil-fuel emissions. The legitimating discourse is found in all Canadian media: broadsheet and tabloid print, television and radio, and social media. Many of the arguments examined here are taken from editorials and commentaries in the Globe and Mail because it markets itself as "Canada's National Newspaper" and as "Canada's leading forum for world-class opinion and debate" (2014). The National Post, business sections of both the National Post and Globe and Mail, Sun Media, as well as television commentaries by privileged definers use the same arguments in favour of increased bituminous sands oil extraction ${ }^{2}$. Those arguments will be analyzed to determine whether they withstand critical scrutiny. Note that the article focuses on probing the how of rhetorical legitimation, and leaves the who largely to another study, hence it focuses on assessing the arguments.

\section{The Case of Canada's Bituminous Sands}

There is exceptionally widespread scientific consensus that human activity, particularly the combustion of fossil fuels, has become an additional driver of climate change. This is the conclusion not only of climatologists but also scientists from a wide variety of fields, as manifested by the IPCC (2014) and national science academies (Royal Society 2010). Most mitigation policies are backloaded incremental ones, but Latin (2012) demonstrated they will fail because they allow carbon to continue being placed in the atmosphere where it accumulates and remains for a century. Technological successes of extracting oil from unconventional sources require more energy and produce more emissions per barrel than

2. The sources are too numerous to reference here, but the arguments can be seen in CAPP (2013) because editorials and commentary largely echo assertions of the petroleum industry. I am confident these arguments capture the overwhelming tendency of media commentary, but the article leaves to future research a quantitative count of commentaries for or against. Geoffrey Simpson is a rare regular commentator in favour of mitigation, a carbon tax and/or cap-and-trade. 
from conventional sources (Davidson and Andrews 2013), thereby increasing emissions and accelerating depletion of this non-renewable resource (Hughes 2009). Extraction of oil from bituminous sands is one of several emerging unconventional sources that has currently resulted in abundance of oil and emissions in North America.

Conservative Natural Resources Minister Oliver branded Canada as having an unmatched environmental record, telling Americans that by supporting the Keystone XL Pipeline they could have oil, jobs, and save the planet from climate change: "Canada is a global environmental leader ... and yes, that includes the oil sands. ... Many opponents are spreading false information about the oil sands, especially its impact on the environment" (Koring 2013: B7). Although media audiences do not passively accept everything they are told, assertions like these constitute what Canadians would like to be true. When repeated in the media by a privileged definer, these reassurances can become normalized in the thinking of many people.

Among wealthy OECD countries, some like Canada, USA, and Australia have disproportionately high per capita $\mathrm{CO}_{2}$ equivalent emissions $-22.05,22.46$, and 25.64 tonnes respectively in 2008 - compared to northern European societies like Sweden, Norway, Denmark, Germany, UK, as well as Japan - 6.98, 11.49, 11.74, 11.98, 10.23, and 10.18 respectively (Conference Board of Canada 2011). Northern European societies are reducing emissions and lowering dependence on fossil fuels whereas Canada is intensifying path dependence on fossil fuels and increasing emissions. In 2009 big emitters, defined by Environment Canada (2010) as facilities emitting 50 kilotonnes of $\mathrm{CO}_{2}$ equivalent or more, ${ }^{3}$ accounted for $34 \%$ of Canada's emissions. That year Alberta produced $47 \%$ of Canada's emissions from big emitters despite having only $10.9 \%$ of Canada's population. Alberta uses coal-fired electricity and has been extracting large amounts of oil from bituminous sands, already exporting 1.6 million barrels per day, and wants more pipelines through the United States and other provinces to increase this by another million barrels per day. "Oil and gas extraction, fossil fuel production and refining, pipelines, fugitive releases, and coal mining were responsible for 51\% of Canada's emissions growth between 1990 and 2009" (Environment Canada 2011: 8). Emissions will grow even faster when underground bituminous sands are exploited.

3. Unless otherwise indicated, the statistics in this paragraph are taken from Environment Canada (2010). Canada's emissions decreased in 2009 because of the global recession and Ontario's closing of some coal-fired electricity generation, but they were still 17\% above the 1990 level (Environment Canada 2011). 
Alberta and Canada refute Castells' hypothesis of an awakening to global warming and an enactment of policies to reverse it (Clarke et al. 2013). Instead his qualification applies: power relationships are defending productivism and consumerism at all costs. Hence it is important to analyze how communication power accomplishes this.

\section{Veiling the Visibility of a Super Emitter}

One way scientific conclusions about anthropogenic climate change are mediated and practices influenced is through media publicity paid by oil, gas and pipeline companies. They no longer just advertise their products in competition against other companies. Now they unite to combat criticism of their environmental performance. The Canadian Association of Petroleum Producers (CAPP 2014) funded a vast, broad-based print and electronic media campaign in major newspapers and television networks in English and French to legitimate bituminous sands oil extraction. ${ }^{4}$ For example, iconic images were staged of restored Boreal forests that had been extractive brownfields, with trees attracting birds and squirrels. However, studies (Royal Society 2010) document that renaturing damage lags far behind brownfield creation. In other ads, a pretty spokeswoman bragged about royalties that finances hospitals and schools for all Canadians, but Alberta receives lower royalty rates than other jurisdictions like Norway, and the Canadian government receives no royalties. More ads showed a Quebec bus manufacturer selling buses to transport workers with the claim that extraction benefits all Canadians. But most equipment used in bituminous sands exploitation was bought in the United States, South Korea, and Japan (Clarke et al. 2013). Caterpillar is a major supplier yet moved its Ontario production to the United States because workers refused to accept a $50 \%$ wage reduction. Other media publicity promoting bitumen has been paid by the oil company Cenovus (2014), the pipeline company Enbridge, the natural gas company Encana and the Alberta and Canadian governments (Cryderman 2013). The latter spent \$24 million on one oil-sands advertising blitz (Boutilier 2013). These paid advertisements reframe these fossil-fuel, climate-change causing activities to give them a positive image and mask and legitimate emissions.

\section{Diverting Attention from Disproportionate Emissions}

Paid advertisements are not the only means by which media communication power is exercised, the news spinned, and uncomfortable knowledge

4. These ads that appeared in the print and electronic media in English and French over the past years can be found on the CAPP (2014) website. 
excluded. The article now turns to its central object of study, namely Canadian media commentary found in sources specified in the methodology. It will analyze some of the main arguments used to transform problematic emissions into a sociocultural nonproblem and construct quiescence concerning bitumen pollution.

1. Claims that Canada produces less than $2 \%$ of the world's emissions, and its bituminous sands only a fraction of that, are emphasized. Lost in this rhetorical translation is that Canada and Alberta have only 0.5 and $0.05 \%$ respectively of the world's population, so their people are disproportionately producing emissions, especially Alberta, because of big emitters exploiting bitumen and coal.

2. 'Intensity based indicators' are deployed to show lower emissions per barrel of bitumen extracted now than two decades earlier. The apparent improvement is misleading because this unconventional extraction produces more emissions per barrel than Alberta's own conventional oil extraction, hence making global warming worse. Environment Canada (2011: 8) documented that "oil sands mining, extraction and upgrading activities were about 1.6 times more GHG-intensive than conventional oil production in 2009" even after the bitumen industry reduced its per-unit emissions by $29 \%$ since 1990. Despite the improvement, oil sands activities still produce $60 \%$ more emissions per barrel than conventional oil, and the number of barrels is increasing rapidly. Since global warming results from the absolute amount of emissions, a true emissions decrease would require that emissions per barrel be reduced faster than the number of barrels increases, which is not happening.

3. When comparing bitumen to conventional oil, proponents emphasize $15 \%$ to $40 \%$ more emissions in the 'full life cycle' from source to combustion rather than the $300 \%$ more emissions extracting and upgrading it (Kunzig 2009: 48) because emissions in transporting, refining, and combusting bitumen are similar to conventional oil. The lower number appears more appealing even though the excess emissions entering the atmosphere remain as high.

4. Reference comparisons for bituminous oil are diverted from Alberta's conventional oil to heavy Venezuelan crude. This dumbing down makes the comparison more attractive, with Alberta's oil sands only producing $2 \%$ more life-cycle emissions than Venezuelan crude (USDS 2013: ES-15), but it is an inadvertent admission that emissions are worsening as unconventional sources replace conventional oil (Davidson and Andrews 2013). 
5. A carbon-capture-and-storage (CCS) demonstration project in Weyburn Saskatchewan has been deployed rhetorically to claim carbon is being stored. However the vast majority of emissions-producing facilities are not using CCS. Alberta has a carbon tax on big emitters, but it is too tiny to restrain emissions or fund CCS and serves mainly for public relations.

6. In international negotiations, the petroleum industry and Alberta and Canadian governments shifted the emissions reference comparison from 1990 - specified in the Kyoto Protocol - to 2006, after a huge increase in emissions occurred from bitumen extraction.

\section{The Language of Communication Power}

As Freudenburg (2005: 105) stated, power is embedded in words that then reinforce predispositions. For example, in the United States the word 'entitlements' refers to health care rather than to cheap gas and tollfree roads, whereas the term 'rights' refers to bearing arms, including assault weapons, and unlimited donations to political parties. Similarly language has been framed to legitimate emissions in Canada.

1. The expression 'tar sands', used since European settlers found them, was replaced by 'oil sands' to maximize their appeal by underscoring oil. ${ }^{5}$ The accurate term is 'bituminous sands'.

2. The non-renewable resource of oil is called a 'commodity', which diverts attention from the fact it is finite and will eventually be gone because of rapid extraction. This discursive cleansing by association constitutes a loss of verbal accuracy because oil is very different from renewable commodities like wheat and lumber.

3. The bituminous sands are branded an 'oil patch' to create an impression of smallness, but the 'patch' of the Boreal forest containing bitumen measures 141,000 square kilometers of which 4,700 square kilometers are presently exploited. When environmentalists exaggerate the size of bitumen exploitation (e.g. claiming it is as big as England), they are severely criticized by bitumen promoters, who are permitted to exaggerate at will. In a media interview, Canada's Prime Minister Harper stated that American environmentalists were trying to turn Canada into a big national park. In his 2012 Davos speech, Harper claimed that aboriginal and environmental groups want to delay the Northern Gateway Pipeline for the sake of delay,

5. The bitumen industry clearly believes 'oil sands' is more appealing, as indicated by its irritation when Obama used 'tar sands'. 
thereby dismissing their goal of acting for their people and the environment.

4. Oil was produced by nature's processes over millions of years using the sun's energy and is extracted by oil companies. Nevertheless the latter claim in the media they 'produce' oil.

5. The euphemism 'well to wheels' is employed by the bitumen industry for the full cycle. However, the oil comes from bituminous sand not a well, and the carbon ends up in the atmosphere not in wheels. Accuracy would require the phrase 'carbon transferred from the ground to the atmosphere'.

6. The expression 'knowledge-based, high technology, innovative' economy is usually reserved for economies creating value-added products, services, and designs, such as those of Germany, Switzerland, and South Korea, not those exporting raw non-renewable resources, such as Saudi Arabia, Russia, and underdeveloped countries. The export of raw bitumen not even upgraded would not qualify. This does not stop proponents from characterizing it with those labels to veil their environmentally primitive technologies: clearcutting the Boreal forest and not restoring it, combusting natural gas to boil river water to flush bitumen from sand, storing toxic waste in tailings ponds, and emitting more greenhouse gases than pumping oil from wells. Overall the petroleum industry has a low rate of innovation and investment in research (OECD 2011: 188).

7. 'Sustainable development' means development based on renewable resources and on efficient use and conservation of non-renewable ones, not a temporary boom resulting from the export of non-renewable resources. This has not prevented advocates of bituminous exploitation from claiming it is sustainable because large extractable reserves will not be exhausted for 100 years even if massive quantities are exported. But that means the oil will be gone by the end of a human lifetime.

\section{The Sudden Appearance of 'Ethical Oil'}

To legitimate bituminous sands oil extraction and divert attention away from its pollution, Sun Media journalist Ezra Levant (2010) rebranded it "ethical oil". Bituminous oil is more ethical than less polluting Saudi or Iranian oil because Canada does not stone women for adultery or flog gays like Saudi Arabia and Iran. Canada is a democracy, so Canadian bituminous oil is democratic oil. Canada created some nature preserves, so bituminous sands oil is by association environmentally responsible regardless how much emissions it produces. Bituminous oil righteously 
provides Canada with funds to support a democracy, whereas oil royalties give Saudi Arabia money to support a dictatorship. Canada has imported oil from Saudi Arabia since oil began being pumped from the Ghwar oil fields in the 1950s, but middle-eastern oil became suddenly 'unethical' after bitumen oil was found more polluting and emissions-intensive and labeled 'dirty oil' by its critics. The subtext is: buy Canadian ethical bitumen and forget about its pollution.

This rebranding is similar to the reframing of the American gun debate. After the attempted assassination of President Reagan, the National Rifleman's Association initiated a successful media campaign to construct positive representations of guns claiming gun possession is a right ensuring freedom.

The reframing strategy was widely diffused in the media. Levant's book Ethical Oil had an elective affinity with business groups, winning the 2011 Canadian National Business Book Award. Levant (2010), hailed by TV commentator Rex Murphy as "Canada's No. 1 defender of freedom of speech", has been a fierce critic of human rights tribunals. Nevertheless he uses ethical policies concerning rights of women and minority groups to shift attention away from probable harm to vulnerable countries and future generations through the medium of carbon emissions. Bad behavior on one issue is excused by good behavior on another: Canada has a license to pollute because it is a democracy. Although rebranding bitumen from dirty to ethical oil was its main objective, the book was also an attack on environmental groups.

Where will this labeling of commodities as ethical by association stop? The Conservative Canadian government vetoed listing asbestos as a dangerous substance in the Rotterdam Convention so that Canada could sell asbestos to poor countries with inadequate protections, but is Canadian asbestos 'ethical' because it is produced by a democracy that does not persecute women and gays? Can Canada claim to have ethical oil and ethical asbestos no matter how polluting, damaging, and dangerous they are? The branding of Canada's bitumen oil as 'ethical' is absurd because it confuses the elements being discussed: overall Canada is an ethical society, but it has a few unethical practices that make risk for poor societies and future generations through the medium of the environment, such as its sale of asbestos and its high emissions extraction of oil from bituminous sands. Human rights and democracy in Canada are being deployed discursively as a veil to hide its environmental failures of governance. If the concept 'ethical oil' is to be convincing, it would mean oil not having adverse future consequences for vulnerable groups through the medium of the environment. 


\section{The Sudden Disappearance of 'Ethical Oil'}

Levant (2010: 68) argues that the choice the world has is "between Exxon or PetroChina, between the Alberta oil sands or Saudi Arabia" and threatens that "not asking 'then what?' about a U.S. energy tax on the oil sands could mean giving a country like China even greater access". But surely "ethical oil" companies and governments wouldn't make it unethical by exporting it to sustain "a country like China" ruled by the dictatorship of the Communist Party. If buying oil from dictatorships like Iran and Saudi Arabia is unethical, then it is unethical to sell bitumen to dictatorships like China. Nevertheless in January 2012 when American President Obama delayed the Keystone XL Pipeline because it was to cross an aquifer, oil companies and the Alberta and Canadian governments immediately pushed to sell bitumen to China. Bitumen sold to China that contributes to its energy supply and capacity to repress Tibet and threaten Taiwan is indeed a contradictory denouement for 'ethical oil'.

Loudly proclaiming oil from dictatorships unethical but ignoring the ethics of selling it to dictatorships demonstrates that 'ethical oil' is a media propaganda device based on a double standard to legitimate bitumen. When planning began to export bitumen to China, that rhetorical device became contradictory. So instead of living up to the standards of 'ethical oil', those standards were abandoned as rhetorically useful only briefly after bitumen extraction was criticized as 'dirty' but before planning to sell it to China. The evolution of discourse concerning ethics of oil was determined by the evolution of profit-seeking interests. After Obama delayed the pipeline, TransCanada Pipelines quickly agreed to move it to avoid the Nebraska aquifer because long-term profits were still foreseen. Bitumen companies and the Alberta and Canadian governments on the contrary developed a Northern Gateway Pipeline strategy of selling bitumen to China to resist pressure to install expensive technologies to decrease emissions from bitumen extraction and reduce pollution.

\section{What is Left Unsaid in Canadian Mass Media Discourse}

\section{Inconvenient Findings in Reports}

The American State Department's Keystone XL study (USDS 2013: ES15) found that oil sands "crudes are more GHG-intensive than the other heavy crudes they would replace or displace in U.S. refineries, and emit an estimated 17 percent more GHGs on a life-cycle basis than the aver- 
age barrel of crude oil refined in the United States in 2005". This confirms the validity of the designation 'dirty oil' for bitumen. The Canadian media (see McCarthy 2013: A3) ignored this important finding, highlighting instead the study's bizarre contention that the Keystone Pipeline will not worsen global emissions because Canada would find other ways to export bitumen. This is like saying: why bother requiring recycling since polluters will find other ways to dump their waste. The American Environmental Protection Agency found this argument of the State Department seriously deficient. If oil comes from bitumen, greater emissions upstream undermine measures to reduce emissions downstream: overall emissions will not decrease if stricter fuel efficiency regulations are accompanied by a change to vehicle fuel extracted from bituminous sands instead of conventional wells. Canada would face less opposition to pipelines if it reduced bitumen emissions to conventional oil levels.

The International Energy Agency (IEA 2012) predicted annual world renewable energy use will increase by 1,300 million tons of oil equivalent between 2010 and 2035. This was spun in the Canadian media as indicating fewer carbon emissions, decreased water use, and decreased air pollution (Blackwell 2012: B10). This feel-good assertion was achieved by ignoring the report's accompanying prediction: fossil fuel use will increase even more, by 2,700 million tons, including an increase of 800 million tons of coal, the most polluting fossil fuel. Concerning what actually occurred, the report documented that use of coal grew faster over the previous decade than total renewables. Anthropogenic carbonization of the atmosphere is worsening even as Canadian media commentators claim the problem is being solved.

\section{Reneging on a Ratified International Commitment}

Canada signed the Kyoto Protocol and ratified a commitment to reduce its emissions by $6 \%$ relative to its 1990 emissions. It failed to achieve that promised reduction, instead increasing emissions by $26 \%$. Then after a change of government, it reneged on its commitment and withdrew from the Protocol. There is almost no criticism by prominent media commentators about this broken promise.

\section{The Environmental Injustice of Greenhouse-Gas Emissions}

Wealthy societies that have been high carbon emitters for a century discount past emissions, which is illogical because carbon remains in the atmosphere for a century causing a greenhouse effect. Recent-emitter, developing nations like Brazil, Russia, India, and China (BRIC) argue more plausibly that equitable mitigation needs to be proportional to an- 
thropogenic carbon in the atmosphere. Moreover their per capita emissions are three times lower than those of OECD countries (OECD 2008: 2). China is a commonly used scapegoat in the Canadian media to divert responsibility from Canada and Alberta, with no recognition that China's high emissions result from its huge population. Its recent emissions have enabled many of its citizens to escape poverty, whereas for wealthy countries, increases in emissions result from growing already high consumption. These are not excuses for developing nations to follow the high carbon path of wealthy societies but instead reasons why wealthy countries should lead the way to low-carbon economies. Although all peoples are threatened by global warming, it is typically poor countries having tiny per capita emissions that are most vulnerable. Wealthy nations have shown little interest in adequately financing the adaptation of poor nations to consequences disproportionately caused by wealthy nations. These injustices of greenhouse-gas emissions have largely disappeared from the Canadian media. Global responsibility for humanity as a whole, as hypothesized by Beck, is underdeveloped in the Canadian media.

\section{The Pace of Bituminous Sands Exploitation}

Former Alberta Premier Lougheed argued that bitumen extraction should be made more beneficial by building upgraders in Alberta rather than accelerating raw bitumen exports, already at 1.6 million barrels per day. This would give time to train Canadian labour for jobs thereby reducing unemployment and decreasing labour shortages, to innovate technologies to reduce greenhouse-gas emissions, to decrease fresh water contamination, and to restore Boreal forests being transformed into brownfields. He advocated maximizing Alberta's long-term benefits by using bitumen extraction as leverage to diversify the economy and save benefits in a sovereign wealth fund (Campbell 2013). Since oil will likely become more valuable as the world's population and prosperity grow, oil in the ground is like money in the bank. Rapidly draining Alberta's oil is disingenuous. Rather than exporting massively into a temporary American shale oil boom at low prices, a less frenetic pace would await higher prices when upgrading is profitable. Lougheed's advice has fallen victim to a disappearing act in media commentary, so the pace of extraction is accelerating. Media commentaries advocate building pipelines rapidly and using rail transportation to ship raw bitumen to Asia and rushing to pipe it to the United States to compete with shale oil. A vicious circle sets in whereby the more bitumen exported, the lower the price, the less profitable local upgraders, and more raw bitumen needs to be exported to maintain benefits. An important argument for Americans in favour of 
the Keystone XL pipeline is that its content will be refined in the United States and not exported as raw bitumen, but Canadian media commentators fail to apply a similar argument to Canada.

The rapid exploitation of non-renewable resources results in boomand-bust economies. A large quantity of resources does not prevent the bust but merely postpones it. A bust is threatened not only when all the bitumen is extracted but also because deeper in situ bitumen is more costly to extract. Alberta's hectic pace of exporting its non-renewable resources brings on the bust more quickly than moderating the rate of extraction, diversifying its economy, and becoming less vulnerable to oil price fluctuations (Clarke et al. 2013). There is little media attention to the finite amount of Alberta's extractable oil, even as massive quantities are exported, and hence little awareness of the bust waiting after the bitumen boom.

Canada has a long history selling staple resources to Britain and the United States, which then sold finished products back (Innis 1962). This was criticized as Canadians being hewers of wood and drawers of water, but at least the resources were renewable: lumber, wheat, beaver pelts, etc. In the 1990s a high technology, knowledge-based, innovative, value-added sector developed led by companies like Nortel, Mitel, JDS, and Research in Motion. Since the millennium, the Canadian economy has regressed and become increasingly dependent on exporting resources, but now non-renewable ones like raw bitumen. This evokes little critical media commentary.

\section{The Net Effect on Provinces}

Unlike most countries, Canada's natural resources are under provincial control. This creates only minor economic inequalities for most resources, but since oil is such a valuable resource, it results in economic benefits concentrated in Alberta. Exporting huge amounts of oil inflates the Canadian currency and makes it difficult to sell other exports. This is a well documented phenomenon affecting many countries called the 'Dutch Disease' by The Economist or 'resource curse' (Auty 1993) to which Canada is not immune (Beine et al. 2009). It can be managed, as Norway shows (Campbell 2013), by investing royalties outside the country to prevent a currency increase, which is not being done by Alberta. Rather than promoting research concerning the net effect of the bitumen industry on other provinces, even raising the issue is decried by media commentators as being divisive.

British Columbia is worried that if bitumen is transported across its territory and shipped from its shores, it will get the risk but little benefit. Hence it expects to be paid for accepting risk, and not merely if damage 
occurs. The bitumen industry's refusal to pay for risk has received little media attention.

\section{A Huge Media Mistake}

Climate scientists Weaver and Swart (2012) published an article in $\mathrm{Na}$ ture calculating that extraction, upgrading, and combustion of all the oil in Alberta's bituminous sands would have less effect on global warming than extracting and combusting all the planet's coal. The Globe and Mail presented this in its front page headline as "Science rides to aid of oil sands": "Weaver's overall analysis will provide additional lobbying force for Canadians seeking to overturn or change the EU fuel-quality directive" (Vanderklippe 2012a: A3) and reported that the Canadian Association of Petroleum Producers stated it might calm "the inflamed rhetoric from the other side". The newspaper ran a second article entitled "Oil sands proponents get a PR boost" (Vanderklippe 2012b). This has been the use to which the study was put despite the first article quoting Weaver stating he is "absolutely opposed" to the Northern Gateway pipeline and that policies like the EU fuel directive are probably the way of the future (Vanderklippe 2012a: A3). In an online comment, Weaver (2012) wrote: "It would be a huge mistake to interpret our results as some kind of a 'get out of jail free' card for the tarsands. While coal is the greatest threat to the climate globally, the tarsands remain the largest source of greenhouse gas emission growth in Canada and are the single largest reason Canada is failing to meet its international climate commitments".

Comparing Alberta's bituminous sands oil to all the planet's coal, which is far more abundant, diverts attention from evidence that bituminous extraction is making emissions worse. ${ }^{6}$ A more appropriate comparison would be with conventional oil wells, which shows more emissions and pollution from bitumen per barrel extracted (Davidson and Andrews 2013). This episode demonstrates the oil sands industry's second-order power (Murphy 1988: Ch 7) to profit from independent research of well-intentioned but politically naïve natural scientists, whose research was given a hugely mistaken spin in the media.

6. The comparison of bitumen with coal is frequently used to justify emissions from bitumen extraction, with Canadian media commentators calling the United states 'hypocritical' for criticizing Alberta's bitumen while it combusts coal. They ignore that American use of coal and its emissions are decreasing whereas Canadian extraction of bitumen and resulting emissions are increasing. Demonizing environmentalists as 'hypocritical' is their favorite tactic: Al Gore, James Cameron, etc., should either restrict themselves to horses or shut up about bitumen, preferably the latter. 


\section{Environmentalists in Words but Not in Actions}

Margaret Wente is a much read columnist in Canada's national newspaper because of her entertaining personal style and skills at spinning the news. When a cold snap hits Toronto, a "Whatever happened to global warming?" (Wente 2013) column quickly appears. Particularly significant was her (Wente 2012: F9) column claiming "it's safe to say we're all environmentalists now" because everyone's heard about Rachel Carson, companies talk about 'triple bottom lines', national energy boards do environmental hearings, fierce debates occur about environmental concerns, etc. She contends that, far from depleting fossil fuels, human ingenuity keeps finding them in tar sands, shale, deepwater, the Arctic, etc., and "thanks to our strong legacy of environmental responsibility, we'll be able to set environmental and safety standards for the world" (Wente 2012: F9).

In that column entitled "The agony of David Suzuki", she admits Canada's preeminent science educator - zoologist and geneticist Dr. Suzuki - disagrees with her depiction of Canada's strong legacy of environmental responsibility, especially in recent years. He concedes defeat in his effort to sensitize Canadians to looming dangers, concluding the environmental movement has weakened and the environmental agenda is being rolled back. Ingenuity has been limited to making money by extraction; hence it has accelerated atmospheric carbonization, fresh water contamination, and brownfielding the Boreal forest. Canadians through their companies and governments have acted irresponsibly concerning the environment, thereby setting a bad example for the world. Short-term economic goals have diverted ingenuity away from mitigating long-run environmental harm. Wente dismisses Suzuki's scientific, evidence-based risk analysis as one more "doomsday scenario" and relies instead on her faith in market-driven technological development. For her, present actions of companies and governments in Alberta and Canada are fine. It is paradoxical scientists like Suzuki are skeptical that science will find timely solutions to environmental problems like climate change and therefore suggest socio-economic changes, whereas media opinion leaders with little training in science like Wente promote a blind faith in production science and advocate charging full-speed ahead in the fossil-fuel habitus.

It's safe to conclude we're all environmentalists in words, but not in actions (Milne et al. 2009). However it is actions that affect the environment, and words only do where they influence actions. Wente (2012: F9) contends "the problem isn't that the environmental movement has failed to explain this message [of Suzuki]. It's that the people have rejected it". 
That is probably correct, in part due to media campaigns by the fossilfuel industry and media opinion leaders like Wente to convince people to reject it. Telling people what they wish to hear is more readily acted upon than inconvenient evidence which implies the necessity of modifying received practices.

\section{Then What?}

Levant (2010) raises the important 'then what' question if environmentally harmful bitumen extraction is opposed, but gives a superficial answer that then there will be nothing. The choice is instead between dirty oil and cleaning dirty oil at least to conventional oil levels. Since fossil fuels will likely be used for a long time (Jaccard 2005), oil from bituminous sands will be extracted. As Freudenburg (2006) would say, it is the way oil is extracted that creates environmental damage and risk. There are alternatives to the present approach that would reduce environmental impacts. 1) Instead of natural gas to supply energy for extraction and upgrading, a nuclear reactor could be deployed. If ever there was a place to accept risks of a nuclear reactor, it is in the isolated bituminous sands region. Renewable energy from wind, solar, and hydro could be maximized. These innovations would virtually eliminate fossil-fuel emissions. Or 2) since natural gas produces lower emissions than coal and is cheap and abundant, it could replace coal for Alberta's electricity generation so that decreased emissions there would offset bituminous sands emissions.

More generally, the alternatives are 1) Alberta's present model of low royalties, low flat income taxes, no sales tax, tiny heritage fund, and excessively high emissions, or 2) Norway's model (Nelsen 1991; Campbell 2013) of high royalty rates, high corporate taxes, a sales tax and carbon tax, an enormous sovereignty fund for future generations, a state-owned oil company accountable to the population, lower emissions from oil extraction, and offsetting difficult-to-reduce emissions by paying to reduce emissions elsewhere. Norway's approach has led its present population to be as prosperous as Alberta's and to come through the recent recession deficit free. Such alternatives to present Canadian practices are extremely rare in media commentaries.

\section{Conclusions}

Castells hypothesized two possibilities concerning anthropogenic global warming: i) a world awakening to danger with policies to reverse it, or 
ii) the defense of productivism and consumerism at all costs. Canada is presently following the second path. Instead of maximizing energy efficiency, adding value, finishing products, and shifting to renewable energy, Canada is increasing its reliance on combusting and exporting its non-renewable fossil fuels for its prosperity. Within Canada, Alberta produces disproportionate greenhouse-gas emissions because of its reliance on coal and bituminous oil extraction. The pursuit of immediate economic benefits of a raw bitumen superexporter has resulted in Alberta and thereby Canada becoming a superemitter. Rather than balancing economic goals and the environment, the fast pace of extracting bitumen contrasts with the slow pace of mitigating emissions and renaturing brownfields.

By focusing on the discursive legitimation of practices that cause anthropogenic climate change, this article showed how communication power in the Canadian media veils the adverse consequences of extracting oil from bituminous sand. Commentary by media opinion leaders mediates the relationship between scientific conclusions and emissions practices. The article examined the staging of discourse used to promote bitumen extraction, and thereby greenhouse-gas emissions. It elucidated the diversionary reframing deployed to cast a favourable gloss on extraction and divert attention from environmental degradation, thereby pushing risk of future harm to the back of the public agenda. It exposed rhetorical devices used, deconstructed the productivist framing, and lifted the media shroud covering counter-arguments, which has the potential to lead to more reasoned debate. The analysis showed how legitimation of emissions was embedded in language and how inconvenient questions were made to disappear in the media. Concern about practices causing climate change was dampened and quiescence was fostered by the Canadian Association of Petroleum Producers and the federal and Alberta governments, supported by privileged definers in the media. Although other factors are involved, such as urban sprawl and fossil-fuel based habitus, rhetorical devices using media communication power are important elements explaining i) the generalized apathy among the Canadian public and policy makers concerning anthropogenic climate change and ii) why Canada's emissions are increasing. Since attempts to legitimate emissions could be replaced by action to reduce emissions, the article ends by highlighting technological and societal alternatives to high emissions oil extraction rarely mentioned in media commentaries.

More generally, the lack of a global responsibility perspective by media opinion leaders is part of the explanation of why science, an institution usually assumed to be particularly influential in reflexive, cosmopolitan modernization, is having little influence in societies like Canada 
when it brings troubling news. Media audiences are intellectually active and not passive recipients of half-truths, but that should not be used to obscure the fact that many privileged media definers are feeding audiences what they want to hear instead of warning them about the scientifically demonstrated danger of fossil-fueled social practices. The media are key institutions in the explanation of why Canada is one of the world's highest per capita greenhouse-gas emitters. They are transforming a scientifically documented environmental problem into a societal non-problem. Emissions are increasing not because climate science isn't pure enough but rather because there are powerful promoters of activities that cause global warming.

The article presents but one investigation into how communication power in mass media discourse mediates between scientific warnings of danger and social practices, inflecting practices in some wealthy societies towards exacerbation of global climate change. More inquiries are needed into how social practices causing environmental problems come to be interpreted as non-problematic, how diversionary reframing results in the public misunderstanding of science, and how the media influence the choice of economic over environmental priorities rather than a balance between the two, as well as differences thereof among societies.

\section{REFERENCES}

Auty, R. 1993. Sustaining Development in Mineral Economies: The Resource Curse Thesis. London: Routledge.

Beck, U. 1995. Ecological Politics in an Age of Risk. Cambridge: Polity. . 1999. World Risk Society. Cambridge: Polity. . 2000. What is Globalization? Cambridge: Polity. 2006 The Cosmopolitan Vision. Cambridge: Polity.

Beine, M., Bos, C., and Coulombe, S. 2009. Does the Canadian Economy Suffer from Dutch Disease? Centre for Research in Economic Analysis. University of Luxembourg. http://wwwfr.uni.lu/recherc/fdef/crea/publications2/ discussion_papers/2009 (Accessed October 22, 2013)

Blackwell, R. 2012. "Renewable power to soar by 2035: IEA". Globe and Mail 13 November: B10.

Boutilier, A. 2013. "Federal government prepares \$24-million oil sands advertising blitz". Financial Post . October 11. http://business.financialpost. com/2013/10/11/federal-government-prepares-24-million-oil-sands-advertising-blitz/? lsa=19b1-fa2b (Accessed February 10, 2014).

Campbell, B. 2013. The Petro-Path Not Taken. Ottawa: Canadian Centre for Policy Alternatives. http://www.policyalternatives.ca/sites/default/files/ 
uploads/publications/National\%20Office/2013/01/Petro\%20Path $\% 20$ Not\%20Taken_0.pdf (Accessed October 22, 2013).

CAPP 2013. Canadian Association of Petroleum Producers. The 2013 Progress Report. http://www.capp.ca/rce/ (Accessed April 11, 2014).

CAPP 2014. Canadian Association of Petroleum Producers. Oil Sands Today. http://www.oilsandstoday.ca/Reports/Pages/Advertising.aspx (Accessed April 11, 2014).

Castells, M. 2009. Communication Power. Oxford: Oxford University Press.

Cenovus Energy 2014. News \& Views. http://www.cenovus.com/news/our-advertising.html (Accessed April 11, 2014).

Clarke, T., Stanford, J., Gibson, D., and Haley, B. 2013. The Bitumen Cliff. Ottawa: Centre for Policy Alternatives.

Conference Board of Canada. 2011. GHG Emissions Per Capita. http://www. conferenceboard.ca/hcp/details/environment/greenhouse-gas-emissions. aspx (Accessed March 23, 2012).

Cryderman, K. 2013. "How Canada's big oil firms are trying to sway public opinion". Globe and Mail http://www.theglobeandmail.com/report-onbusiness/industry-news/energy-and-resources/big-oils-push-to-movethe-mushy-middle/article12464590/ (Accessed February 10, 2014)

Davidson, D. and Andrews, J. 2013. Not All About Consumption. Science, Vol. 339 No. 6125: 1286-7.

Davidson, D. and Gismondi, M. 2011. Challenging Legitimacy at the Precipice of Energy Calamity. New York: Springer.

Environment Canada. 2010. "Overview of the Reported 2009 Greenhouse Gas Emissions". Ottawa: Ministry of the Environment, http://www.ec.gc.ca/ Publications/84468072-E951-45AD-A63E-EA8BEB26F1BC/OverviewOfTheReported2009GreenhouseGasEmissions.pdf (Accessed June 8, 2011).

. 2011. National Inventory Report 1990-2009 Greenhouse Gas Sources and Sinks in Canada. Ottawa: Environment Canada. http://www. ec.gc.ca/Publications/A07097EF-8EE1-4FF0-9AFB-6C392078D1A9/ NationalInventoryReportGreenhouseGasSourcesAndSinksInCanada19902009ExecutiveSummary.pdf (Accessed June 8, 2011)

2013. National Inventory Report 1990-20011 Greenhouse Gas Sources and Sinks in Canada. Ottawa: Environment Canada. http://www.ec.gc.ca/ Publications/A07ADAA2-E349-481A-860F-9E2064F34822/NationaInventoryReportGreenhouseGasSourcesAndSinksInCanada19902011. pdf (Accessed November 1, 2013).

Freudenburg, W. 2005. Privileged Access, Privileged Accounts. Social Forces Vol. 84 (1): 89-114.

2006. Environmental Degradation, Disproportionality, and the Double Diversion. Rural Sociology 71 (1): 3-32. 
Globe and Mail 2014. April 11. http://www.theglobeandmail.com/globe-debate/ (Accessed 11 April 2014).

Hall, S. et al. 1978. Policing the Crisis. New York: Holmes \& Meier.

Hannigan, J. 1995 (2006). Environmental Sociology. London: Routledge.

Hughes, J.D. 2009. The Energy Issue, in T. Homer-Dixon, ed., Carbon Shift. Toronto: Random House of Canada.

IEA International Energy Agency. 2012. World Energy Outlook 2012. Paris: OECD/IEA.

Innis, H. 1962. The Fur Trade in Canada. Toronto: University of Toronto Press.

IPCC Intergovernmental Panel on Climate Change. 2014. Fifth Assessment ReportAR5. http://www.ipcc.ch/report/ar5/index.shtml (Accessed April 14, 2014).

Jaccard, M. 2005. Sustainable Fossil Fuels. Cambridge: Cambridge University Press.

Koring, P. 2013. In pitch to U.S., Oliver touts environmental record. Globe and Mail, 6 March: B7.

Kunzig, R. 2009. The Canadian Oil Boom. National Geographic, Vol. 215, No. 3, pp. 34-59.

Latin, H. 2012. Climate Change Policy Failures. Singapore: World Scientific Publishing.

Lester, L. 2010. Media and Environment, Cambridge: Polity.

Levant, E. 2010. Ethical Oil. Toronto: McClelland \& Stewart.

McCarthy, S. 2013. State Department gives Keystone a boost. Globe \& Mail 2 March: A3.

McCright, A. and R. Dunlap. 2010. Anti-Reflexivity. Theory, Culture, and Society, Vol. 27, No. 2-3: 100-133.

Milne, M.J., Tregidga, H.M., \& Walton, S. 2009. Words not Actions. Accounting, Auditing \& Accountability Journal, 22 (8): 1211-1257.

Murphy, R. 1988. Social Closure. Oxford: Oxford University Press (Clarendon). . 2012. "Sustainability: A Wicked Problem". Sociologica: The Italian Journal of Sociology (2 ) 23 pages. http://www.sociologica.mulino.it/ doi/10.2383/38274. Electronic journal (Accessed October 20, 2013).

Nelsen, B. 1991. The State Offshore. New York: Praeger.

OECD 2008 Climate Change: Meeting the Challenge to 2050. Policy Brief, February. http://www.oecd.org/dataoecd/6/21/39762914.pdf (Accessed October 19, 2013). 
. 2011. Innovative sectors, in OECD Science, Technology and Industry Scoreboard 2011, OECD Publishing. http://dx.doi.org/10.1787/sti_scoreboard-2011-66-en (Accessed October 17, 2013).

Pollack, H. 2005. Uncertain Science... Uncertain World. Cambridge: Cambridge University Press.

Rayner, S. 2010. Trust and the transformation of energy systems. Energy Policy 38: 2617-2623.

.2012. Uncomfortable Knowledge. Economy and Society 41 (1): 107-125.

Royal Society of Canada. 2010. Environmental and Health Impacts of Canada's Oil Sands Industry. Ottawa.

Swart, N.C., and Weaver, A.J. 2012. The Alberta oil-sands and climate. Nature Climate Change, 2 134-136

USDS United States Department of State, Bureau of Oceans, and International Environmental and Scientific Affairs. 2013. Keystone XL Project Executive Summary-Draft SupplementalEIS. Washington. http://keystonepipeline-xl.state.gov/documents/organization/205719.pdf. (Accessed March 1, 2013).

Vanderklippe, N. 2012a. Science rides to aid of oil sands, Globe and Mail 21 February: A1, A3.

2012b. Oil sands proponents get a PR boost, Globe and Mail 22 February: B5.

Weaver, A. 2012. The oilsands are a symptom of the bigger problem of our dependence on fossil fuels. http://www.thestar.com/opinion/editorialopinion/article/1134808--the-oilsands-are-a-symptom-of-the-biggerproblem-of-our-dependence-on-fossil-fuels (Accessed February 22, 2012).

Wente, M. 2012. The Agony of David Suzuki. Globe and Mail 14 April: F9.

.2013. Whatever happened to global warming?. Globe and Mail. 24 January: A13.

Young, Nathan and Dugas, Eric. 2011. Representations of Climate Change in Canadian National Print Media, Canadian Review of Sociology, 48 (1): $1-22$

Raymond Murphy is Emeritus Professor of Sociology at the University of Ottawa, Canada, and Past-President of the Environment and Society Research Committee of the International Sociological Association. He is the author of Sociological Theories of Education (McGraw-Hill Ryerson 1979), Social Closure (Oxford University Press 1988), Rationality and Nature (Westview 1994), Sociology and Nature (Westview 1997) and Leadership in Disaster: Learning for a Future with Global Climate Change (McGill-Queen's University Press 2009). 